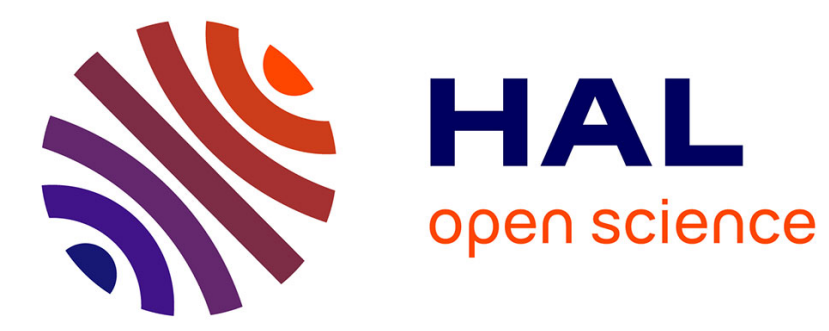

\title{
The $2.2 \AA$ resolution structure of thermolysin (TLN) crystallized in the presence of potassium thiocyanate
} Jean-François Gaucher, Mohamed Selkti, Thierry Prangé, Alain Tomas

\section{To cite this version:}

Jean-François Gaucher, Mohamed Selkti, Thierry Prangé, Alain Tomas. The $2.2 \AA$ resolution structure of thermolysin (TLN) crystallized in the presence of potassium thiocyanate. Acta crystallographica Section D : Structural biology [1993-..], 2002, 58 (12), pp.2198-2200. 10.1107/S0907444902015457 . hal-02880602

\section{HAL Id: hal-02880602 https://hal.science/hal-02880602}

Submitted on 25 Jun 2020

HAL is a multi-disciplinary open access archive for the deposit and dissemination of scientific research documents, whether they are published or not. The documents may come from teaching and research institutions in France or abroad, or from public or private research centers.
L'archive ouverte pluridisciplinaire HAL, est destinée au dépôt et à la diffusion de documents scientifiques de niveau recherche, publiés ou non, émanant des établissements d'enseignement et de recherche français ou étrangers, des laboratoires publics ou privés. 
Acta Crystallographica Section D

Biological

Crystallography

ISSN 0907-4449

\section{Jean-François Gaucher,* Mohamed Selkti, Thierry Prangé and Alain Tomas}

Laboratoire de Cristallographie et RMN Biologiques (UMR-8015, CNRS), Université Paris V, Faculté de Pharmacie, 4 Avenue de I'Observatoire, 75270 Paris CEDEX 06, France

Correspondence e-mail: gaucher@pharmacie.univ-paris5.fr

\section{The $2.2 \AA$ resolution structure of thermolysin (TLN) crystallized in the presence of potassium thiocyanate}

Received 21 May 2002

Accepted 27 August 2002

Bacillus thermoproteolyticus is presented. After dissolving the protein in the presence of KSCN, which avoids the use of DMSO and $\mathrm{CsCl}$, crystals were obtained following the salting-in method. Crystal cell parameters are isomorphous with those previously reported from DMSO/CsCl mixtures. The new $\mathrm{SCN}^{-}$crystal structure has been analyzed. It shows the presence of one thiocyanate ion in the catalytic site and several rearrangements in the $S_{1}$ and $S_{2}$ subsites. These results are in agreement with the measurements of Inouye et al. [(1998), J. Biochem. (Tokyo), 123, 847-852], who observed in solution that the solubility of TLN, which is particularly poor in low ionic strength solutions, increases dramatically in the presence of several neutral salts. The results reported here suggest possible explanations for the solubility increase and for the inhibitory effects of high $\mathrm{SCN}^{-}$ concentrations on thermolysin activity.

\author{
PDB Reference: thermolysin, \\ 1gxw, r1gxwsf.
}

\section{Introduction}

Thermolysin (TLN; EC 3.4.24.27) is a thermostable metalloendopeptidase of molecular weight $36400 \mathrm{Da}$ which is isolated from B. thermoproteolyticus. Crystallographic structures of TLN complexed with a variety of inhibitors have provided evidence for the binding mode of substrates and the catalytic mechanism (Matthews, 1988). However, the role of DMSO and ionic strength in the crystallization process still remains unclear.

Usually, thermolysin and/or its complexes are crystallized after dissolving TLN at high concentration $\left(>200 \mathrm{mg} \mathrm{ml}^{-1}\right)$ in a mixture of $\mathrm{DMSO}$ and calcium acetate or $\mathrm{CsCl}$ by vapourdiffusion of hanging drops against a lowconcentration reservoir (Matthews et al., 1972). In this particular case, the water vapour diffuses from the reservoir to the drop, whose volume increases. The supersaturation of TLN, a prerequisite for crystallization, is reached because of the low solubility of TLN in the absence of DMSO or salts.

The TLN structure, which usually retains the Val-Lys dipeptide, has been refined at $1.6 \AA$ resolution and shows the presence of a DMSO molecule (Holmes \& Matthews, 1982).

Following this standardized method, other structures of TLN cocrystallized with thiolate inhibitors were obtained. They also form a complex with a DMSO molecule (Gaucher et al., 1999).
The mechanism of crystallization implies a salting-in effect. Indeed, at low ionic strength, the concentration of soluble TLN in the presence of precipitate is measured as $0.16 \mathrm{mg} \mathrm{ml}^{-1}$ at $\mathrm{pH} 7.0,278 \mathrm{~K}, 0.2 \mathrm{M}$ sodium acetate (Sazaki et al., 1993). It dramatically increases in the presence of $45 \%(v / v)$ DMSO and $1.4 M$ calcium acetate or $2.5 \mathrm{M} \mathrm{CsCl}$ at $\mathrm{pH}$ 7.2 (Matthews et al., 1972; Holmes \& Matthews, 1982). More recently, Inouye et al. (1998) observed the same increase of solubility in the presence of several neutral salts without DMSO.

The effect of salts is complex: Inouye et al. (1998) reported that salt concentration affected both the solubility and the activation of TLN without any apparent correlation between the two effects.

Firstly, the effect of the anion and cation on solubility (here defined as the soluble protein concentration in the presence of precipitate) was analyzed. The solubility is affected more by anions than cations. Anions dramatically increase the solubility following the reverse order of the Hofmeister series, with an effectiveness $\mathrm{SCN}^{-}>\mathrm{I}^{-}>\mathrm{ClO}_{4}^{-}>\mathrm{NO}_{3}{ }^{-}>\mathrm{Br}^{-}>$ $\mathrm{Cl}^{-}>\mathrm{CH}_{3} \mathrm{COO}^{-}$. The effectiveness of cations follows the order $\mathrm{Na}^{+}>\mathrm{K}^{+}>\mathrm{Li}^{+}$. The authors suggested that this last effect, which did not follow the Hofmeister series, is induced by specific interactions between ions and the enzyme.
(C) 2002 International Union of Crystallography Printed in Denmark - all rights reserved 
Secondly, the effect of neutral salts on the reaction rate of TLN-catalyzed hydrolysis of FAGLA [3-(2-furyl)acryloyl-L-Leu-L-Ala] was investigated. The $k_{\mathrm{cat}} / K_{M}$ increased in an apparent exponential fashion in the presence of $\mathrm{NaCl}, \mathrm{NaBr}, \mathrm{KCl}$ and $\mathrm{NaBr}$. In the presence of $\mathrm{NaSCN}$, the activity reaches its optimum at $1 M$ and decreases at higher concentrations.

In the present paper, we have solubilized TLN to high concentration in KSCN solution and crystallized it by vapour diffusion against a low-concentration reservoir. We are focusing on the specific interactions between thiocyanate and TLN. The crystal structure was then refined to disclose the corresponding interactions.

\section{Crystallization, data collection and processing}

Thermolysin was purchased from SigmaAldrich Co. Since the commercial enzyme powder contains salts, it was first purified by reprecipitation: $3 \mathrm{mg}$ of lyophilized TLN was suspended in $100 \mu \mathrm{l}$ of water and centrifuged at $7200 \mathrm{~g}$. The pellet was freezedried and redissolved in $15 \mu$ of solution $A$ [50 $\mathrm{m} M$ tris(hydroxymethyl)aminomethane$\mathrm{HCl}$ buffer $\mathrm{pH} 8.3,1 M \mathrm{KSCN}, 20 \mathrm{~m} M$ $\mathrm{CaCl}_{2}$ ]. The enzyme concentration was estimated using an $\varepsilon_{280}$ of $56000 \mathrm{M}^{-1} \mathrm{~cm}^{-1}$. $0.5 \mu \mathrm{l}$ drops $\left(87 \mathrm{mg} \mathrm{ml}^{-1} \mathrm{TLN}\right)$ were equilibrated against $1 \mathrm{ml}$ reservoirs of diluted solution $A$ in water. The best conditions were reached with a mixture of $740 \mu \mathrm{l}$ solution $A$ and $260 \mu$ water. Hexagonal crystals appeared in one week at $277 \mathrm{~K}$. The reservoirs were then diluted with $0.3 \mathrm{ml}$ water. Crystals grew to their final size within two more weeks.

Diffraction data were recorded at the LURE synchrotron facility, Orsay, France at $283 \mathrm{~K}$ on the DW21b wiggler beamline (1.375 $\AA$ wavelength; $300 \mathrm{~mm}$ diameter MAR Research image-plate detector system). Data were processed with MOSFLM (Leslie, 2001) interfaced with the CCP4 suite of programs (Collaborative Computational Project, Number 4, 1994).

The crystal space group is $P 6_{1} 22$, with unit-cell parameters $a=b=93.17$, $c=130.63 \AA$, one molecule per asymmetric unit and $39 \%$ solvent. 58898 reflections were measured and reduced to 15898 unique reflections $\left[R_{\text {merge }}=8.6 \%, I / \sigma(I)=\right.$ 7.3], with $92.2 \%$ completeness within the range $18.5-2.18 \AA\left[R_{\text {merge }}=24.1 \%\right.$ and $82.7 \%$ completeness in the last resolution shell 2.30-2.18 $\AA$, with $I / \sigma(I)=2.3$ ].

\section{Refinement}

The starting model was the native TLN structure crystallized in a mixture of DMSO and $\mathrm{CsCl}$ (PDB code 8tln; Holmes \& Matthews, 1982). The thermal parameters of atoms were set to the average value deduced from the Wilson plot $\left(\langle B\rangle=18.6 \AA^{2}\right)$.

Because the crystal was isomorphous with 8 tln, the refinement began with a rigid-body least-squares refinement (CNS 1.1; Brünger et al., 1998), followed by refinements of the atomic positions by energy minimization at the resolution of $2.25 \AA$.

At this stage, grouped thermal parameters (two for each residue) were refined and 134 water molecules were progressively added in several cycles of energy minimization and grouped thermal parameter refinements.

In the structure, a Fourier difference map reveals a shift of Tyr157 in the catalytic active site and the presence of bottle-shaped electron density near the catalytic zinc.

The resolution was then extended to $2.18 \AA$ and individual thermal parameters were refined. The bottle-shaped density, which was initially interpreted as two

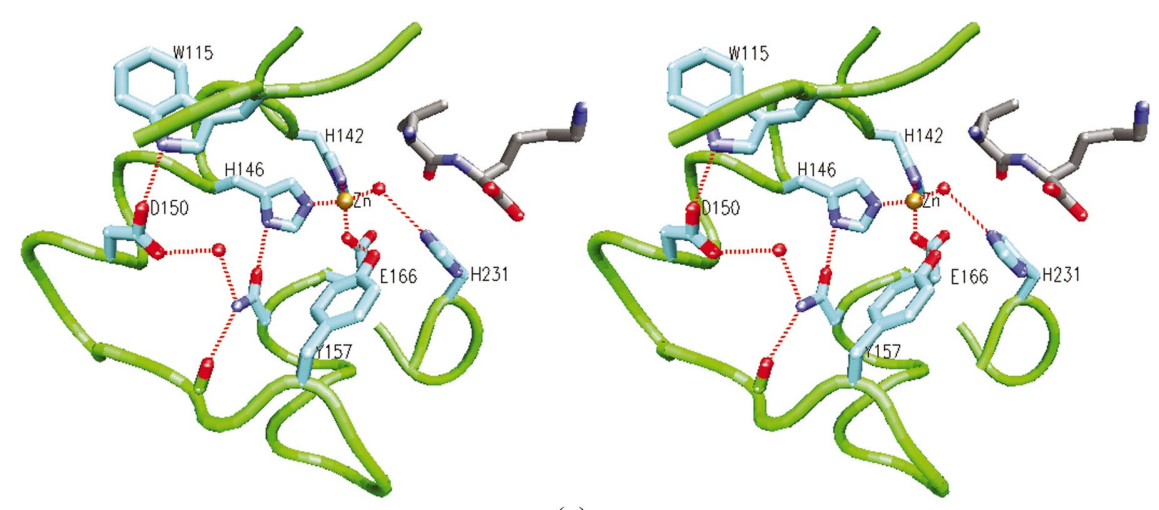

(a)

discrete water molecules, showed unrealistically low $B$ factors. It was then modelled as an $\mathrm{SCN}^{-}$ion, which now perfectly fits the electron density.

Refinement ended with an overall $R$ factor of $16.3 \%$ and $R_{\text {free }}=21.4 \%$. The statistics of the refinement are given in Table 1.
Table 1

Values in parentheses are for the highest resolution bin (2.32-2.18 А).

\begin{tabular}{ll}
\hline Resolution range $(\AA)$ & $19-2.18$ \\
Completeness $(\%)$ & $92.4(83.9)$ \\
$R$ factor $/ R_{\text {free }}(\%)$ & $16.3 / 21.4(18.3 / 24.2)$ \\
Estimated coordinate error & $0.18 / 0.15$ \\
$\quad($ Luzzati plot $/ \sigma)(\AA)$ & \\
RMS deviations from ideal values & \\
$\quad$ Bond lengths $(\AA)$ & 0.007 \\
Bond angles $\left({ }^{\circ}\right)$ & 1.3 \\
Dihedral angles $\left({ }^{\circ}\right)$ & 22.8 \\
Improper angles $\left({ }^{\circ}\right)$ & 0.73 \\
Isotropic thermal factor restraint $(\mathrm{RMS} / \sigma)$ \\
Main-chain bond $\left(\AA^{2}\right)$ & $1.44 / 1.50$ \\
Main-chain angle $\left(\AA^{2}\right)$ & $2.02 / 2.00$ \\
Side-chain bond $\left(\AA^{2}\right)$ & $2.57 / 2.00$ \\
Side-chain angle $\left(\AA^{2}\right)$ & $3.51 / 2.50$ \\
\hline
\end{tabular}

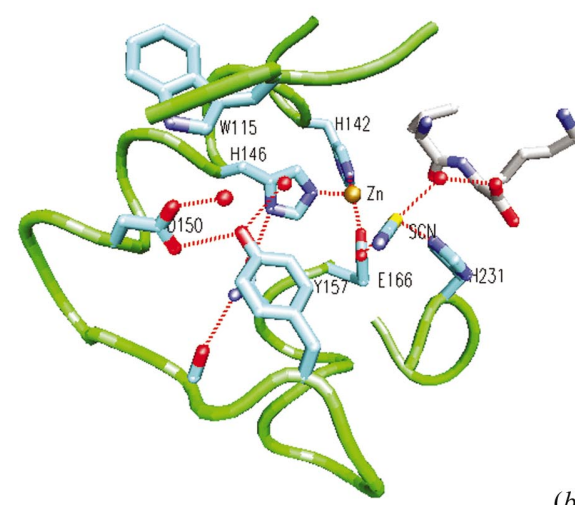

(b)

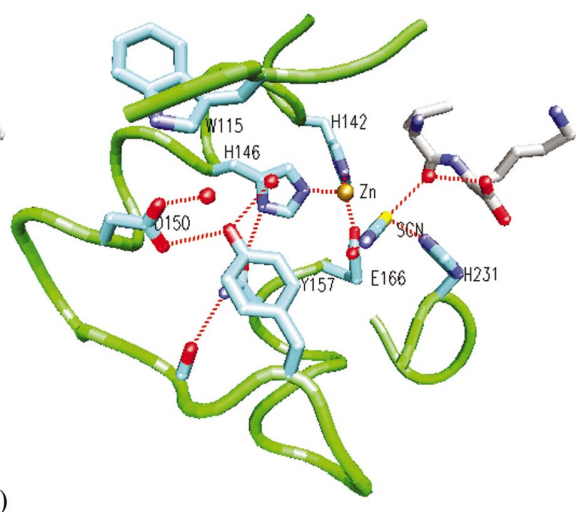

Figure 1

Stereoimages illustrating the mode of binding of the SCN ion to TLN and the rearrangement of the subsite S1-S2. (a) Partial structure of the active site of TLN crystallized in the presence of DMSO/CsCl. $(b)$ Partial structure of the same active site of TLN crystallized in the presence of KSCN. Tyr157 rotates about the $\chi_{1}$ angle toward Asp150. The SCN ion tightly binds His231, Glu166 and a water molecule (VMD; Humphrey et al., 1996). 


\section{Results and discussion}

The use of thiocyanate as a crystallizing agent has been popularized in the last decade following the work of Riès-Kautt \& Ducruix (1989, 1991). The efficiency of thiocyanate in crystallizing basic $\mathrm{pI}$ proteins has been demonstrated in the cases of erabutoxin B (Saludjian et al., 1992) and lysozyme (Vaney et al., 2001). In most cases, a thiocyanate ion is retained within the crystal structure and shows strong interactions with positively charged residues (Hamiaux et al., 1999).

In the refined structure of $\mathrm{TLN} / \mathrm{SCN}^{-}$, 316 residues, 180 water molecules, four $\mathrm{Ca}$ atoms and one $\mathrm{Zn}$ atom were characterized. It also includes, in addition to the usual ValLys dipeptide located in the S1'-S2' catalytic subsites, one well defined thiocyanate.

The TLN structure itself is virtually identical to the structure obtained from $\mathrm{DMSO} / \mathrm{CsCl}$. The main differences are observed in the active site: the hydrogenbonding network between residues implied in the catalysis mechanism is disturbed by the $\mathrm{SCN}^{-}$ion located in the vicinity of the zinc (Fig. 1).

In TLN crystallized from $\mathrm{DMSO} / \mathrm{CsCl}$, the zinc ligands (His146, His142, Glu166 and a water molecule) form a tetragonal coordination. In the new structure, the zinc coordination is no longer symmetrical: the water molecule is shifted away by the $\mathrm{SCN}^{-}$. The $\mathrm{S}$ atom moves to a distance of $3.1 \AA$ from the $\mathrm{Zn}^{2+}$. Consequently, the Glu166 carboxylate is displaced and its OE1 atom now binds the zinc instead of OE2.

Surprisingly, the thiocyanate $\mathrm{S}$ atom is strongly coordinated to TLN residues: it is $2.6 \AA$ from Glu166 OE2, which seems protonated. It is also $2.4 \AA$ from the NE2 atom of the positively charged His231 and $3.0 \AA$ from a water molecule.

In $\mathrm{DMSO} / \mathrm{CsCl}$ structures, the hydroxyl group of Tyr157 is tightly hydrogen bonded to Glu166 (2.6 $\AA$ ). In the presence of SCN, this conformation is no longer possible because of a steric clash with the thiocyanate. Tyr157 rotates about $\chi_{1}$ and is now hydrogen bonded to Asp150 (2.9 $⿱$ ) and a water molecule ( $3.0 \AA$ ).

The Asp150 residue is also shifted: its short hydrogen bond with $\operatorname{Trp} 115$ (2.8 ̊), as observed in the $\mathrm{DMSO} / \mathrm{CsCl}$ structure, is now disrupted and its carboxylate group binds a water molecule $(2.7 \AA)$ and the hydroxyl group of Tyr157.

The new structure must be related to some properties observed in solution of TLN in the presence of $\mathrm{SCN}^{-}$and neutral salts. Firstly, the solubility was shown to increase in the presence of $\mathrm{SCN}^{-}$. The calculated isoelectric point of TLN, taking into account the four $\mathrm{Ca}^{2+}$ and the $\mathrm{Zn}^{2+}$ coions, is 6.8. The charge on TLN is then -2 and -5 at $\mathrm{pH} 7.2$ and 8.3 , respectively. Consequently, the specific interaction of $\mathrm{SCN}^{-}$and TLN contributes to significantly increase the net negative charge of the protein. This leads to increased solubility.

Secondly, the enzymatic activity is enhanced by the ionic strength (Inouye, 1992; Inouye et al., 1998), but in the case of thiocyanate and to a lesser extent with $\mathrm{LiBr}$ and $\mathrm{LiCl}$, the salt has an inhibitory effect at high concentration. In the new structure described here, the Tyr157 conformation and the presence of $\mathrm{SCN}^{-}$in the catalytic site prevent the substrate binding and consequently might be the reason for the competitive inhibitory effect observed by Inouye and coworkers.

\section{References}

Brünger, A. T., Adams, P. D., Clore, G. M., DeLano, W. L., Gros, P., Grosse-Kunstleve, R. W., Jiang, J. S., Kuszewski, J., Nilges, M., Pannu, N. S., Read, R. J., Rice, L. M., Simonson, T. \& Warren, G. L. (1998). Acta Cryst. D54, 905921.

Collaborative Computational Project, Number 4 (1994). Acta Cryst. D50, 760-763.

Gaucher, J. F., Selkti, M., Tiraboschi, G., Prangé, T., Roques, B. P., Tomas, A. \& Fournie-Zaluski, M. C. (1999). Biochemistry, 38, 1256912576.

Hamiaux, C., Prangé, T., Riès-Kautt, M., Ducruix, A., Lafont, S. \& Veesler, S. (1999). Acta Cryst. D55, 103-113.

Holmes, M. A. \& Matthews, B. W. (1982). J. Mol. Biol. 160, 623-639.

Humphrey, W., Dalke, A. \& Schulten, K. (1996). J. Mol. Graph. 14, 33-38, 27-28.

Inouye, K. (1992). J. Biochem. (Tokyo), 112, 335340.

Inouye, K., Kuzuya, K. \& Tonomura, B. (1998). $J$. Biochem. (Tokyo), 123, 847-852.

Leslie, A. G. W. (2001). MOSFLM Program For Autoindexing and Integrating $X$-ray Diffraction Data, Version 6.11. MRC Laboratory of Molecular Biology, Hills Road, Cambridge, England.

Matthews, B. W. (1988). Acc. Chem. Res. 21, 333340 .

Matthews, B. W., Jansonius, J. N., Colman, P. M., Schoenborn, B. P. \& Dupourque, D. (1972). Nature (London), 238, 37-43.

Riès-Kautt, M. \& Ducruix, A. (1989). J. Biol. Chem. 264, 745-748.

Riès-Kautt, M. \& Ducruix, A. (1991). J. Cryst. Growth, 109, 20-25.

Saludjian, P., Prangé, T., Navaza, J., Ménez, R., Guilloteau, J. P., Riès-Kautt, M. \& Ducruix, A. (1992). Acta Cryst. B48, 520-531.

Sazaki, G., Ooshima, H., Kato, J., Harano, Y. \& Hirokawa, N. (1993). J. Cryst. Growth, 130, 357367.

Vaney, M. C., Broutin, I., Retailleau, P., Douangamath, A., Lafont, S., Hamiaux, C., Prangé, T., Ducruix, A. \& Riès-Kautt, M. (2001). Acta Cryst. D57, 929-940. 